\title{
Educational status of orphanages: A study in Kamrup Metro (Urban) District, Assam, (India).
}

\author{
Authors: Dr. Angonjam Annu Devi ${ }^{1}$; Afrina Borborah ${ }^{2}$
}

Associate Prof., PQSE, University of Science \& Technology, Meghalaya ${ }^{1}$;

Lecturer, Ataur Rahman College of Education,Udmari Kalgachia, Barpeta, Assam ${ }^{2}$;

E-mail:annu.ango@gmail.com ${ }^{1}$; afrina2009@gmail.com ${ }^{2}$

DOI: 10.26821/IJSRC.9.5.2021.9504

\begin{abstract}
In common usage, a child (or a young animal) that has lost both parents is called an orphan. Deaths of parents bring major changes in the life of a child, making an orphan or vulnerable child $(\mathrm{OVC})$. This unfortunate change may involve moving from a middle or upper class urban home to a poor rural relative's home, separating from siblings and without due considerations of their needs, they could be admitted to an orphanage home/institution. The present study is to find out the educational status of orphans in terms of well equipped classrooms, up to date education system, teachers' teaching in the orphan homes/orphanages fulfil their educational needs, children developing themselves for future, sufficient modern and scientific equipments for teaching, library facility for the children and availability of library books. Present study adopted survey method where questionnaire, interview and observation technique were used as tools. 50 (fifty) orphaned children of 5 (five) orphanages in Kamrup Metro (Urban) District, Assam (India) were the sample of the study using simple random sampling. Percentage and bar diagram were used for statistics technique. It was found that most of the orphanages have well infrastructure, environment and good atmosphere which is most important in educating them. Secondly, the teachers as well as the fathers, mothers, caretakers, sisters are found to be of very friendly nature and they are very much helpful to the children at any time in fulfilling their dreams. This study has brought light to the various educational problems of the orphans which are of great importance as children are the builder of the nation and education should be the first priority.
\end{abstract}

Key words: Education, Orphanages, Kamrup Metro (Urban) District, Assam.

\section{INTRODUCTION}

According to Oxford Dictionary the word "orphan" which is a noun means a child whose parents are dead and bereaved (a child) of its parents. The word orphan derived from the Greek word "orphanos" which means 'bereaved'. In common usage, only a child (or a young animal) who has lost both parents is called an orphan. Some definitions as advanced by researchers are "orphan is someone who lacks support or care or supervision or someone deprived of parents or who's natural are absent or dead or whose parents are not there to bring him up." An orphan or vulnerable child (OVC) is a child under the age of 18 whose mother, father, both parents, or a primary caregiver has died, and who is in need of care or protection (Namibian Government definition, 2002). Deaths of parents introduce a major change in the life of a vulnerable child. This change may involve moving from a middle or upper class urban home to a poor rural relative's home. It may involve separation from siblings, which is often done arbitrarily when orphaned children are divided among relatives without due considerations of their needs or sometimes could be admitted to an orphanage institution. The children, who choose to move with relative, may suffer. It may mean the end of a child's opportunity for education because of lack of schooling expenses. Those children who choose not to move or who may not have any other relative to go to may be forced to live on their own, constituting child-headed families. All those changes can easily affect not only physical, but also 
Volume 9 Issue 5 May 2021

the psychological well-being of a vulnerable child. They can be very stressful as they pose new demands and constraints to children's life. It is feared that many children may find it difficult to adapt to the new changes. Children who are frustrated, fearful and depressed may fail to concentrate in class, and therefore, perform badly. Failure by the school and the home systems to recognize these symptoms and address them will aggravate the child's psychological problems. Naimisha Mehta (2012) conducted a research on "The problems in measuring the educational performance of Indian orphans: The effectiveness of the education provided at the St. Catherine of Siena Home and School for Destitute Children in Mumbai, India." The purpose of this paper is to study the education system in India, analyze its structure and assess the standards applied to private and public schools around the city of Mumbai. Upon analysis, the results will then be applied to orphanage schools in Mumbai to see if the same standards are applied there. Using St. Catherine of Siena Home and School for Destitute Children in Mumbai as a case study, it will be shown that the Indian government neglects to include orphanage schools like St. Catherine's under their realm of responsibility. As a result, the quality of education administered at orphanage schools like St. Catherine's is not up to par with the rest of the city's schools. This also reveals the fact that although the Indian government has made great accomplishments in the education sector over the last few decades, the work is not over, and this major act of discrimination and neglect of marginalized groups such as orphans needs to be remedied as soon as possible.

Kinsley Mubita Lishomwa (2013) conducted a research in the Mongu District of Zambia on, "A Comparitive Study Of Guardians/Parents involvement into Orphaned and Non-Orphaned Children's Education in Mongu Disrict. The purpose of this study was to compare parental involvement to guardian involvement in nonorphaned and orphaned children's education respectively. This involvement was looked at from two perspectives: involvement levels of parents/guardians through their own self-evaluation measured against what their own children perceived about them. Whether or not there was a significant difference in involvement between parents and guardians, was the hypothesis that was tested. A sample size of 313 respondents was used: Self-administered questionnaires were distributed to 180 learners (non-orphaned and orphaned) and 120 parents/guardians. Some parents/guardians, 8 teachers and 5 Head teachers were subjected to structured interviews. V.Oyedele et al (2016) found that the orphaned students' performance is poor resulting from the challenges they face in their lives. It was also found that the support from the Government and other stakeholders to deal with the challenges facing orphaned students in academic performance is very minimal in relation to the existing number of orphaned students. Bonsa Shume (2019) indicated that, 1) there were no efforts made by schools, educational stakeholders and the government to eradicate the challenges facing orphaned students and to foster academic performance of orphaned children, 2) No academic and financial support provided to orphaned students in their respective classes, 3) No plan of action for the enhancement of a good school performance to orphaned children and 4) No established strategies to support the orphaned children financially or make close connection with educational stakeholders and Non-Governmental Organizations to support the orphaned children 5) No identified (person in school to help, follow and monitor orphaned learners, 6) No remedial actions designed for Orphaned children attending education in orphan homes, 7) No regular meeting with parents to discuss about Orphaned children's related issues, and 8) No mechanisms put in place to ensure an equal and friendly environment for all the children in the school irrespective of their unique characteristics.

\section{NEED OF THE STUDY}

The orphan children have to undergo several problems: Children who live in the orphanage do not have their families. Children who live in the orphanage though get homely environment but at the same time they feel to be very lonely. Children who live in orphanage always strive for the love of their parents. The need of the study is to find out why children land up on orphanage. So, for the above problems we have to undertake scheme for the upliftment both socially and educationally and have to implant it. Training of the functionaries is an important need for the welfare and development of the orphan children. The need of the study is to 
Volume 9 Issue 5 May 2021

aim at promoting the educational status of the orphaned children working and living at orphanages of Kamrup Metro (Urban) District, Guwahati, Assam and to provide service for their care and education. From the above analysis, it becomes clear that the problem of orphan children is a grave one of which there is general awareness now. Today, we realize the need to respect the inner strength and abilities of the orphaned children and to build their self-image as self-developing young person. Hence, our practice have to be based on understanding these children and responding to the nature of the service they require further than a pre-conceived and stereotyped nation of the case of children.

\section{OBJECTIVE OF STUDY}

To find out the educational status of orphan children in terms of:-
a. Well equipped classrooms
b. Up to date education system
c. Teachers teach properly in the schools and fulfil children's educational needs
d. Children developing themselves for future
e. Sufficient modern and scientific equipments for teaching
f. Library facility for the children
g. Availability of library books.

\section{DELIMITATION OF THE STUDY}

The present study was delimited to only 50 (fifty) orphaned children living in 5 (five) orphanages of Kamrup Metro (Urban) District, Assam, India.

\section{METHODOLOGY}

Present study was a survey method where questionnaire, interview and observation technique were used as tools. 50 (fifty) orphaned children of 5 (five) orphan homes were the samples of the study using simple random method. Percentage and bar diagram were used for statistics technique.

\section{RESULT AND DISCUSSION}

Table 1: Whether the classroom is well equipped.

\begin{tabular}{|l|l|c|}
\hline \multirow{2}{*}{$\begin{array}{l}\text { Type of } \\
\text { response }\end{array}$} & \multicolumn{2}{|c|}{$\begin{array}{l}\text { Whether the class room is well } \\
\text { equipped }\end{array}$} \\
\cline { 2 - 3 } & No. of children & Percentage (\%) \\
\hline a) Yes & 30 & 60 \\
\hline b) No & 20 & 40 \\
\hline Total: & $\mathbf{5 0}$ & $\mathbf{1 0 0}$ \\
\hline
\end{tabular}

\subsection{INTERPRETATION:}

From the above Table 1, it is found that $60 \%$ of the institutions provide well equipped classroom fulfilling the needs of the children and $40 \%$ of institutions does not have modern facilities and thus, they cannot fully satisfy the needs of the children. So, the classroom should be well equipped so that the children are not deprived of their educational needs.

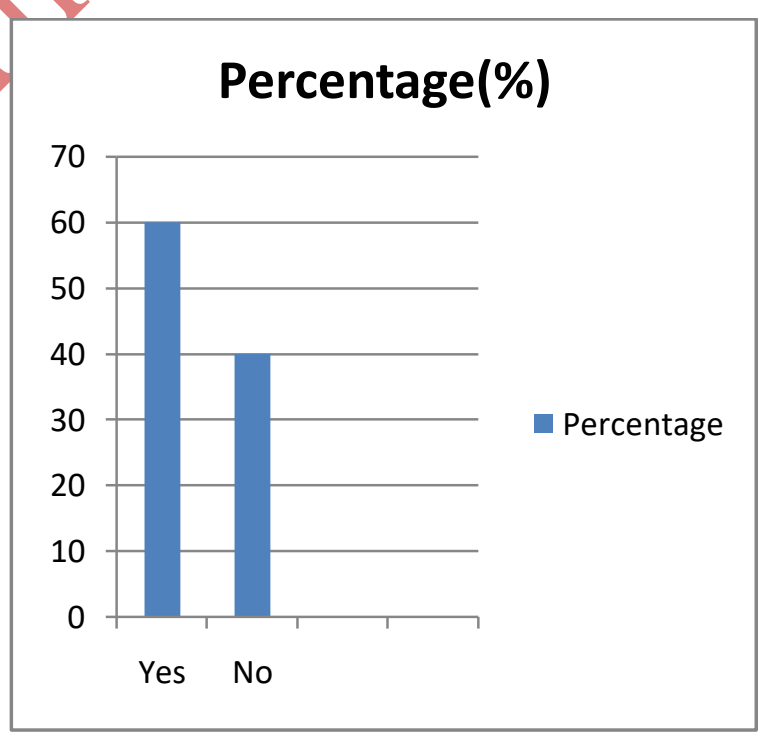

Fig I: Graphical representation showing percentage of institutions with or without well equipped classrooms. 
Volume 9 Issue 5 May 2021

Table 2: Whether the level of education system is up to date or not.

\begin{tabular}{|c|c|c|}
\hline \multirow[t]{2}{*}{$\begin{array}{l}\text { Type of } \\
\text { response }\end{array}$} & \multicolumn{2}{|c|}{$\begin{array}{l}\text { Whether the level of education } \\
\text { system is up to date or not. }\end{array}$} \\
\hline & $\begin{array}{l}\text { No. of } \\
\text { children }\end{array}$ & Percentage (\%) \\
\hline a) Yes & 30 & 60 \\
\hline b) No & 20 & 40 \\
\hline Total: & 50 & 100 \\
\hline
\end{tabular}

\subsection{INTERPRETATION:}

From above Table 2, it is found that $60 \%$ of the institutions are following the up to date system of education whereas, level of the rest $40 \%$ are not up to date and the orphaned children in those institutions are deprived of the up to date system of education. Therefore, education system should be upgraded so that the children are educationally forward and not lagging behind.

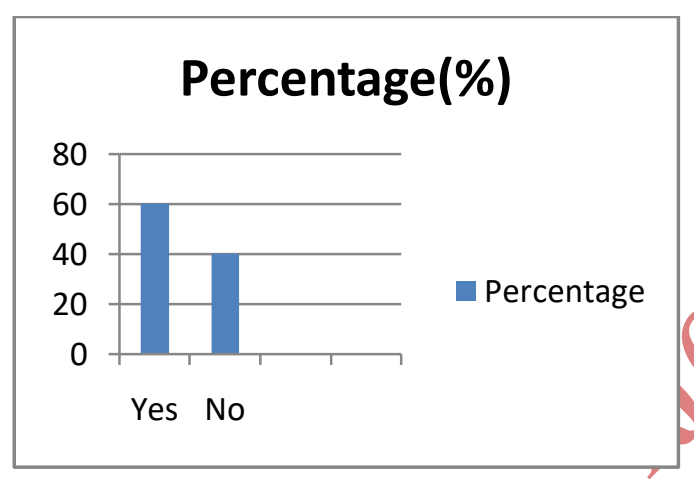

Fig II: Graphical representation in percentage whether the level of education system of institutions are up to date or not.

Table 3: Whether the teachers teach properly in the school and fulfil their educational needs.

\begin{tabular}{|c|c|c|}
\hline \multirow[t]{2}{*}{$\begin{array}{l}\text { Type of } \\
\text { response }\end{array}$} & \multicolumn{2}{|c|}{$\begin{array}{l}\text { Whether the teachers teach } \\
\text { properly in the schools and fulfill } \\
\text { their educational needs or not. }\end{array}$} \\
\hline & $\begin{array}{l}\text { No. of } \\
\text { children }\end{array}$ & Percentage $(\%)$ \\
\hline a) $\quad$ Yes & 25 & 50 \\
\hline b) $\quad \mathrm{No}$ & 25 & 50 \\
\hline Total: & 50 & 100 \\
\hline
\end{tabular}

\subsection{INTERPRETATION:}

Table 3 reveals that only $50 \%$ of the teachers are able to teach properly to the students in the school whereas the rest $50 \%$ teachers are not able to teach the orphaned children properly. Thus, there exists a very large communication gap between the teacher and the taught which makes the child educationally backward.

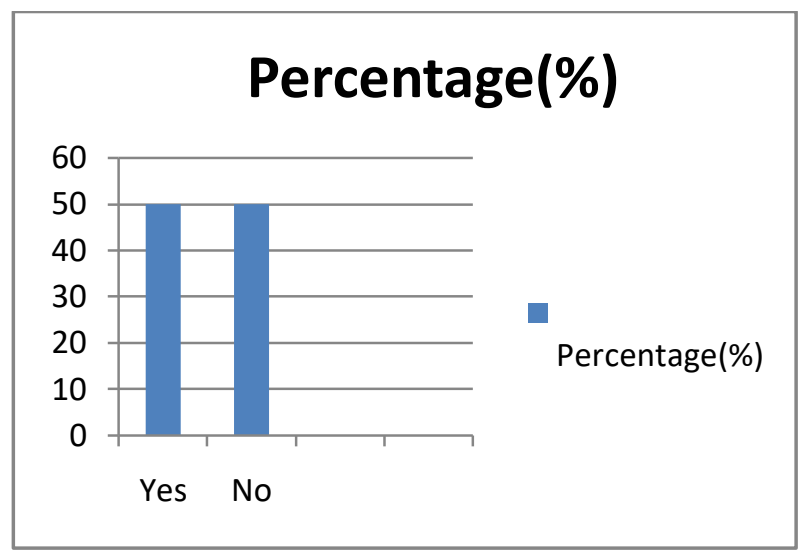

Fig III: Graphical representation in percentage of teachers with ability to teach properly in the schools and fulfil their educational needs and those who cannot teach properly.

Table 4: Whether the children are developing themselves for future.

\begin{tabular}{|c|c|c|}
\hline \multirow[t]{2}{*}{$\begin{array}{l}\text { Type of } \\
\text { response }\end{array}$} & \multicolumn{2}{|c|}{$\begin{array}{l}\text { Whether the children are develop- } \\
\text { ping themselves for future. }\end{array}$} \\
\hline & Absolute Value & Percentage $(\%)$ \\
\hline a) $\mathrm{Yes}$ & 30 & 60 \\
\hline b) $\mathrm{No}$ & 20 & 40 \\
\hline Total: & 50 & 100 \\
\hline
\end{tabular}

\subsection{INTERPRETATION:}

From Table 4, it is found that $60 \%$ of the orphans are developing themselves for the future and $40 \%$ are not developing for future. 
Volume 9 Issue 5 May 2021

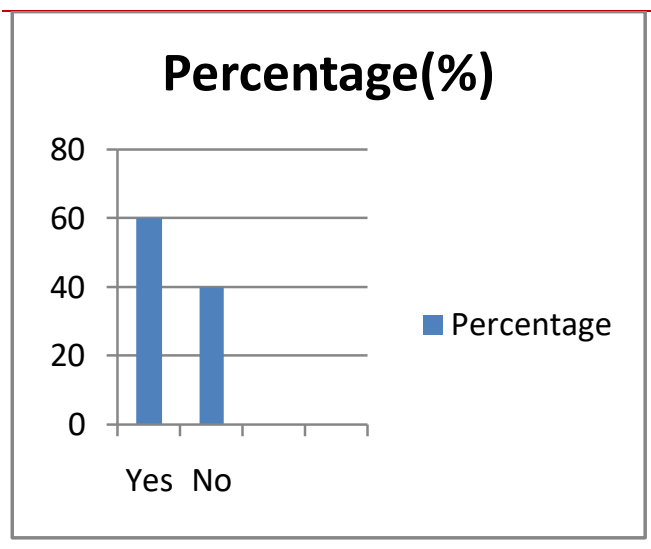

Fig IV: Graphical representation showing percentage of children who are developing themselves for future and those who are lagging behind.

Table 5: Whether the institutions have sufficient modern and scientific equipments for teaching the orphans.

\begin{tabular}{|c|c|c|}
\hline \multirow{2}{*}{$\begin{array}{l}\text { Type of } \\
\text { response }\end{array}$} & \multicolumn{2}{|l|}{$\begin{array}{l}\text { Whether the Institutions have } \\
\text { sufficient modern and scientific } \\
\text { equipments for Teaching the } \\
\text { orphans. }\end{array}$} \\
\cline { 2 - 3 } & $\begin{array}{c}\text { No. of schools } \\
\text { a) Yescentage (\%) }\end{array}$ \\
\hline b) No & 3 & 60 \\
\hline Total: & $\mathbf{5}$ & 40 \\
\hline
\end{tabular}

\subsection{INTERPRETATION:}

Table 5 revealed that $60 \%$ of the institutions provide modern and scientific equipments for fulfilling the needs of the orphaned children and $40 \%$ of institution does not have the modern facilities. Thus, they cannot fully satisfy the needs of the children.

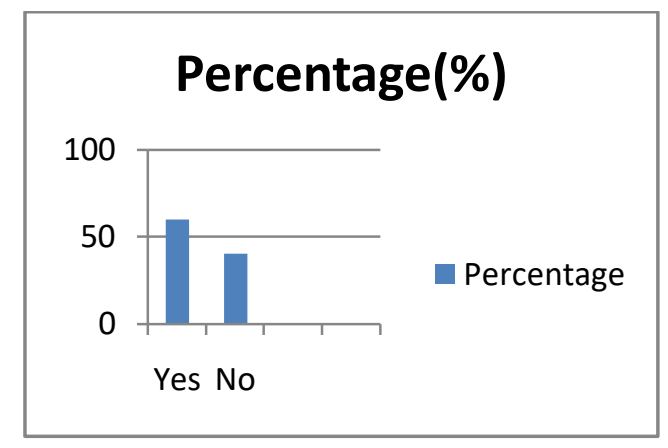

Fig V: Graphical representation showing percentage of institutions with sufficient modern and scientific equipments for teaching the orphans.
Table 6: Whether the institution has library facility for the children.

\begin{tabular}{|r|r|r|}
\hline $\begin{array}{r}\text { Type of } \\
\text { response }\end{array}$ & \multicolumn{2}{|l|}{$\begin{array}{l}\text { Whether the institution has library } \\
\text { facility for the children. }\end{array}$} \\
\cline { 2 - 3 } & No. of schools & Percentage (\%) \\
\hline a) Yes & 4 & 80 \\
\hline b) No & 1 & 20 \\
\hline Total: & $\mathbf{5}$ & $\mathbf{1 0 0}$ \\
\hline
\end{tabular}

\subsection{INTERPRETATION:}

From Table 6, it is found that $80 \%$ of the orphanages are provided with proper library facility whereas the rest $20 \%$ of the institutions not given proper library facility.

\section{Percentage(\%)}

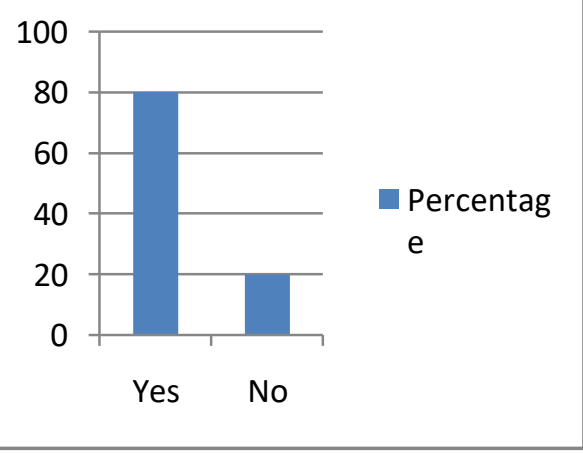

Fig VI: Graphical representation showing percentage of institutions getting proper library facility.

Table 7: Availability of library books in the school.

\subsection{INTERPRETATION:}

Table 7 reveals that books are available in the library of $60 \%$ schools whereas $40 \%$ schools do not 
Volume 9 Issue 5 May 2021

get books in the library which is essential for the children to fulfil their educational needs.

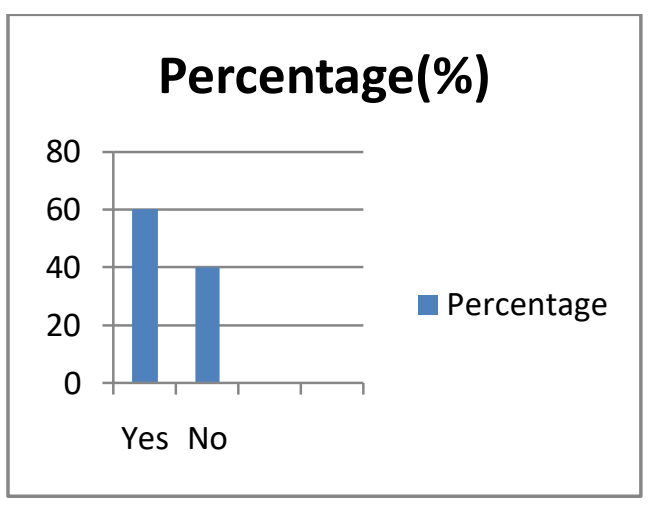

Fig VII: Graphical representation showing percentage of school where library books are available.

\begin{tabular}{|c|c|c|}
\hline \multirow[t]{2}{*}{$\begin{array}{l}\text { Type of } \\
\text { response }\end{array}$} & \multicolumn{2}{|c|}{$\begin{array}{l}\text { Whether library books are available } \\
\text { in the school library. }\end{array}$} \\
\hline & No. of schools & Percentage (\%) \\
\hline a) Yes & 4 & 80 \\
\hline b) No & 1 & 20 \\
\hline Total: & 5 & 100 \\
\hline
\end{tabular}

\section{SUGGESTIONS}

1. Mothers, sisters, fathers and caretakers of orphan homes should be trained periodically in the matter of child care.

2. The organization should give more scope to the children regarding higher education.

3. Proper guidance and counselling should be given to the children from time to time.

4. Modern education system should be introduced in the orphanages so that the children get the up to date knowledge of the present education system.

5. New scientific methods of classroom teaching should be introduced which makes learning more fruitful and effective for the learners.

6. The teachers of the institution should take utmost care of the students and they should be both cooperative and helpful in nature in order to fulfil the dreams of the children.

7. A prerequisite for teachers is to be supportive and recognize and be aware of the struggles of orphans and their particular needs. It is the duty of the teachers to observe all round development of a child and giving immediate solutions to any problem faced by the child.

8. As children are like buds in the garden and should be nurtured carefully and lovingly as they are the future of the nation so the government as well as local bodies should take initiative in creating awareness to the public so that they can help out with monetary support as most of the orphanages are run by donations and sale of small crafts the children make in order to fulfill their basic educational needs.

\section{FURTHER RECOMMENDATIONS}

The following are the recommendations given by the researcher concerning "Status of Orphaned children and their Educational needs at orphanages"-

1. A similar study may be repeated on a large sample covering the whole of Kamrup Metro (Urban) District, Assam.

2. A comparative study may be undertaken on the status of orphans of different districts of Assam and other States of India as a whole.

3. A study may also be undertaken on the adjustment problems faced by the orphans in school and other educational institutions.

4. Historical research studies on the history of orphanages and the orphan problems of Kamrup Metro (Urban) District, Assam can be undertaken.

\section{CONCLUSION}

This study has brought light to the various educational problems of the orphans which is of great importance because children are the builder of the nation and education should be the first priority. Each and every child of orphanages should be given basic educational needs and they should not be deprived of it. In this research conducted particularly in the Kamrup Metro (Urban) District area, it was found that most of the orphanages have well infrastructure, environment and good atmosphere which are most important in educating them. Secondly, the teachers as well as the fathers, mothers, caretakers, sisters are found to be of very friendly nature and they are very much helpful to the children at any time and they try to fulfil their dreams. They are treated as a normal child and 
Volume 9 Issue 5 May 2021

never treated as orphans. Love, affection, care, proper nourishment is found provided to the children. Majority of their educational needs are found fulfilled by those institutions and they receive almost the same modern facilities as well as well equipped classrooms with scientific and modern technologies. But, there are few orphanages which are still deprived of such upgraded facilities and thus, those children remain educationally backward. So, those institutions should make provisions for the children so that they get up-to-date facility and they should move on with the present generation.

\section{REFERENCES}

[1]. Bonsa Shume (2019) Orphan children's school performance, hindering challenges and role of the school(In the case of some selected Primary Schools in Iluababor Zone, Ethiopia), International Journal of Multicultural and Multi-religious understanding 6(3),312-330.

[2]. Koul, Lokesh (2013): Methodology of educational research, Vikas Publishing House Pvt. Limited.

[3]. Mubanga Musonda Ch. (2011) An Investigation into Zambian Parents' Involvement in their Children's Education in Selected Rural Schools of Central Province, An unpublished dissertation of the Degree of Master of Education in Sociology of Education to the University of Zambia,pp.1-73

[4]. Naimisha Mehta (2012) The problems in measuring the educational performance of Indian orphans: The effectiveness of the education provided at the St. Catherine of Siena Home and School for Destitute Children in Mumbai, India, unpublished Dissertation of the Degree of master of education of Mumbai university.

[5]. Nyamukapa, C. A., Gregson, S., Lopman, B., Saito, S., Watts, H. J., Monasch, R., \& Jukes, M.C.H. (2008): HIV- associated orphan hood and children's psychosocial distress: theoretical framework tested with data from Zimbabwe. American Journal of Public Health, 98 (1): 133141.

[6]. Nzala, M.A (2006): Parent involvement in the education of intellectually challenged children: A case of special selected units in Lusaka District.
(Unpublished M.A thesis). Lusaka. University of Zambia. .

[7]. V. Oyedele, W. Chikwature \& P. Manyange (2016) Challenges facing orphaned students and the effects on academic performance O-level commence at Samaringa Cluster Secondary schools, International journal of academic research and reflection. Vol.4(3),pp.37-45.

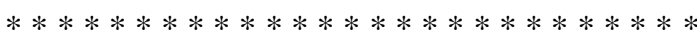

